\title{
Ligularia philanthrax (Asteraceae), a new species from a coal mining region of Kyrgyzstan
}

\section{Lazkov, Georgy A.}

$2019-10$

Lazkov, G A \& Sennikov , A N 2019 , ' Ligularia philanthrax (Asteraceae), a new species from a coal mining region of Kyrgyzstan ', Annales Botanici Fennici , vol. 56 , no. 4-6 , pp. 355-359 . https://doi.org/10.5735/085.056.0421

http://hdl.handle.net/10138/313661

https://doi.org/10.5735/085.056.0421

unspecified

publishedVersion

Downloaded from Helda, University of Helsinki institutional repository.

This is an electronic reprint of the original article.

This reprint may differ from the original in pagination and typographic detail.

Please cite the original version. 


\title{
Ligularia philanthrax (Asteraceae), a New Species from a Coal Mining Region of Kyrgyzstan
}

\author{
Authors: Lazkov, Georgy A., and Sennikov, Alexander N. \\ Source: Annales Botanici Fennici, 56(4-6) : 355-359 \\ Published By: Finnish Zoological and Botanical Publishing Board \\ URL: https://doi.org/10.5735/085.056.0421
}

BioOne Complete (complete.BioOne.org) is a full-text database of 200 subscribed and open-access titles in the biological, ecological, and environmental sciences published by nonprofit societies, associations, museums, institutions, and presses.

Your use of this PDF, the BioOne Complete website, and all posted and associated content indicates your acceptance of BioOne's Terms of Use, available at www.bioone.org/terms-of-use.

Usage of BioOne Complete content is strictly limited to personal, educational, and non - commercial use. Commercial inquiries or rights and permissions requests should be directed to the individual publisher as copyright holder.

BioOne sees sustainable scholarly publishing as an inherently collaborative enterprise connecting authors, nonprofit publishers, academic institutions, research libraries, and research funders in the common goal of maximizing access to critical research. 


\title{
Ligularia philanthrax (Asteraceae), a new species from a coal mining region of Kyrgyzstan
}

\author{
Georgy A. Lazkov ${ }^{1} \&$ Alexander N. Sennikov²,3,
}

\author{
1) Laboratory of Flora, Institute of Biology, Kyrgyz National Academy of Sciences, 720071 Bishkek, \\ Kyrgyz Republic \\ 2) Botanical Museum, Finnish Museum of Natural History, P.O. Box 7, Fl-00014 University of \\ Helsinki, Finland (*corresponding author's e-mail: alexander.sennikov@helsinki.fi) \\ 3) Herbarium, Komarov Botanical Institute of Russian Academy of Sciences, Prof. Popov Str. 2, \\ $R U-197376$ St. Petersburg, Russia
}

Received 4 June 2019, final version received 20 Aug. 2019, accepted 20 Aug. 2019

Lazkov G.A. \& Sennikov A.N. 2019: Ligularia philanthrax (Asteraceae), a new species from a coal mining region of Kyrgyzstan. - Ann. Bot. Fennici 56: 355-359.

\begin{abstract}
Ligularia philanthrax Lazkov \& Sennikov sp. nova (Asteraceae) is a new species from Kyrgyzstan, narrowly distributed in the Turkestan Mountain Range. It differs from the most similar species, L. pavlovii (Syrdarya Karatau Mts., Kazakhstan) by having fewer scales at its stem base, oblong-obovate basal and lower cauline leaves with narrow herbaceous sheaths, and by having more numerous longer ligulate flowers. Ligularia philanthrax occurs in the Sülüktü coal mining region and is considered Critically Endangered because of its restricted distribution, anthropogenic impact and a high level of grazing.
\end{abstract}

Ligularia (Asteraceae) is a moderately speciesrich genus in the tribe Senecioneae, subtribe Tussilagininae (Pelser et al. 2007, Nordenstam et al. 2009), whose estimated species number varies from 140 (Liu \& Illarionova 2011) to over 150 (Pojarkova 1961). The maximal country-level species diversity of the genus occurs in China, with 123 species ( 89 endemic; Liu \& Illarionova 2011). The arid mountains of Central Asia are not particularly suitable for this genus; only 17 species were recorded in this vast territory, with the greatest diversity in the most humid mountains of northeastern Kazakhstan (Pojarkova 1961, Zuckerwanik 1993).

Only few of the Central Asian species of Ligularia are narrow endemics. Among these, L. pavlovii (Lipschitz 1931) is confined to the Syrdarı Qarataý (Syrdarya Karatau) Mts., a relatively small mountain range in the northwestern part of the Western Tian-Shan that harbours many plant endemics. Kamelin (1990) estimated the number of endemic species and subspecies in this territory at 150. Ligularia pavlovii was placed in a monotypic section, $L$. sect. Glossophyllum because of its unique feature: the presence of scale-like reduced leaves at the stem base (Pojarkova 1961). So far, this character has not been known from any other member of the genus.

During a recent inventory of vascular plants of the Turkestan Range in Kyrgyzstan (Ganybaeva 2009), an unusual plant of Ligularia was collected. This plant had some scale-like reduced leaves at the stem base but immediately differed from L. pavlovii by their number and texture, and also by the basal leaf shape and in the number 


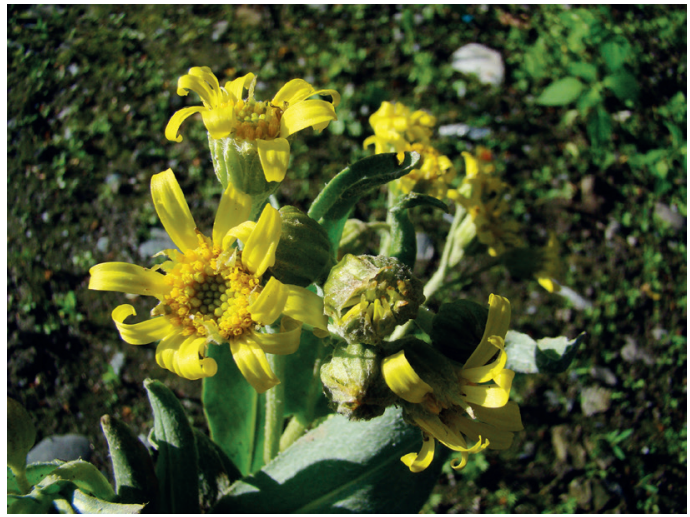

Fig. 1. Flowering heads of Ligularia philanthrax.

of ligulate flowers in capitula (Table 1). These characters provided a firm evidence that we are dealing with another local endemic of Ligularia, which is formally described here.

Vascular plants of the watershed of the Isfana and Laylak rivers (Turkestan Range) were studied by M.R. Ganybaeva in 2009, supervised by the first author. Herbarium collections were identified and deposited in FRU. The locality of the new species was revisited in 2019 to observe the population.

Taxonomic literature (Pojarkova 1961, Zuckerwanik 1993, Liu \& Illarionova 2011) was examined to determine the relationships of the new species. The species description largely follows Pojarkova (1961) and Liu and Illarionova (2011). A distribution map was made using the same procedure as in Lazkov and Sennikov (2017).

Toponyms and personal names in the Kazakh and Kyrgyz languages were transliterated according to the national Latin scripts. The spelling of toponyms in Kyrgyzstan follows Ömürzakov et al. (1988). Romanization of taxonomic authors' names follows original publications, as advised in Rec. 46B.1 of Turland et al. (2018).
Ligularia philanthrax Lazkov \& Sennikov, sp. nova (L. sect. Glossophyllum) (Figs. 1 and 2)

TYPE: Kyrgyzstan. Turkestan Range (N side): NE of Vostochny Village, 5-7 km E of Shyrykty Pass, juniper thickets on rocks, 19 April 2019 G.A. Lazkov (holotype LE, isotypes FRU, MW). - Paratype: Same locality, 9 May 2007 M.R. Ganybaeva (FRU).

Etymology: The species name is derived from Ancient

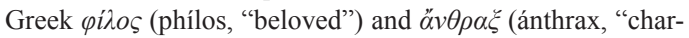
coal").

Species nova a Ligularia pavlovii squamis rosulatis paucioribus herbaceis (nec membranaceis), foliis basalibus oblongo-obovatis (nec oblongo-ellipticis) et ligulis pluribus (12-15, nec ca. 8) longioribus (12-14 mm, nec ca. $7 \mathrm{~mm}$ longis) differt.

Rhizome short, with numerous thin roots and fibrous remains of old petioles, branched. Plants greyish-green, arachnoid-puberulent. Stems erect, $1-4,25-40 \mathrm{~cm}$ tall, ca. $0.3 \mathrm{~cm}$ in diam. at base, striate. Sterile rosettes few to several, usually adjacent to flowering stems, with a few scales and developed leaves. Outer leaves of sterile rosettes reduced to sheaths; sheaths narrow, herbaceous. Inner leaves of sterile rosettes developed, petiolate; petiole shorter than lamina, unwinged or upper winged, base herbaceous, sheath narrow; lamina oblong-obovate, $6-14 \mathrm{~cm}$ long, $1.5-3.5 \mathrm{~cm}$ wide, with a midvein expressed below, entire, apex rotund to obtuse, base gradually attenuate. Basal leaves of fertile stems completely reduced to sheaths, surrounded with abundant fibrous remains of old petioles. Cauline leaves (under synflorescence) 2-4; lower ones shortly petiolate, with herbaceous sheaths, oblong-obovate; others sessile, oblong to oblanceolate, shorter than internodes,

Table 1. Diagnostic characters of Ligularia pavlovii and L. philanthrax. Data on L. pavlovii from Pojarkova (1961).

\begin{tabular}{lll}
\hline Characters & L. pavlovii & L. philanthrax \\
\hline Reduced basal leaves & numerous & few \\
Lamina of developed basal leaves & oblong-elliptic, apex usually & oblong-obovate, apex usually \\
& cuneate & subrotund \\
Sheaths of developed basal leaves & inflated, membranaceous & narrow, herbaceous \\
Remnants of old petioles & meagre & abundant \\
Ligulate flowers & ca. 8, elliptic, ca. $7 \mathrm{~mm}$ long & $12-15$, linear, 12-14 mm long
\end{tabular}


Fig. 2. Plants of the type specimen of Ligularia philanthrax.

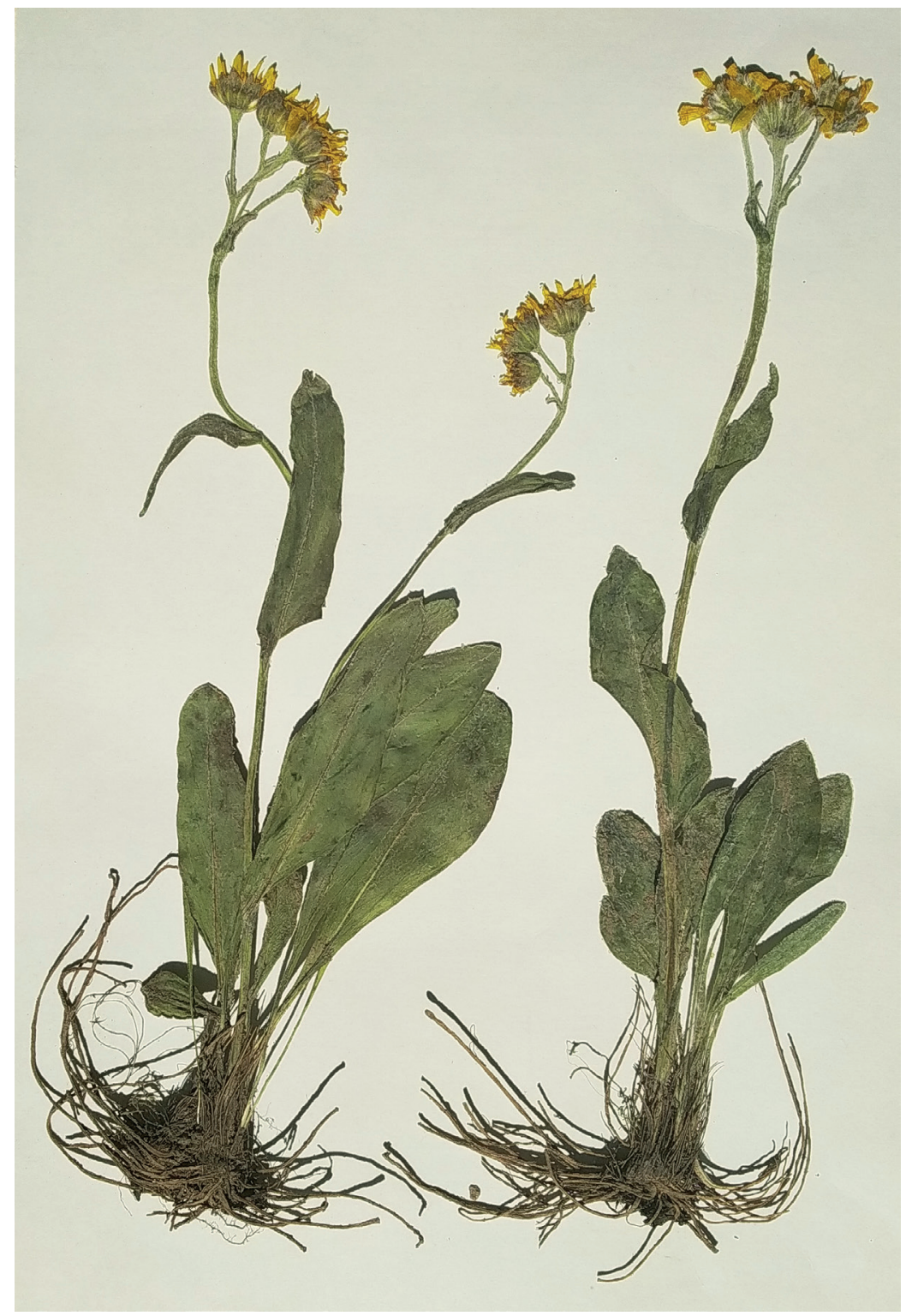

subacute, auriculate to amplexicaul. Synflorescence subcorymbose, very lax, branches $1-8 \mathrm{~cm}$ long. Capitula 2-4, supplementary bracts 1-2, linear. Involucre turbinate, in 2 rows. Phyllaries 10-12, 10-12 mm long, outer ones oblong, with a wide membraneous margin, inner ones lanceolate, with a narrow margin, all attenuate or caudate at apex. Ray florets $12-15$, yellow; lamina 12-14 mm long, $2.5-3 \mathrm{~mm}$ wide. Tubular florets numerous, $10-11 \mathrm{~mm}$ long, narrowly campanulate, tube ca. $5 \mathrm{~mm}$ long, lobes ca. $1 \mathrm{~mm}$ long. Achenes (unripe) cylindric, 6-12 mm long, ribbed, glabrous. Pappus 10-11 mm long, scabrous, white. Flowering in May.

Distribution AND habitat. Pamir-Alay: Turkestan Range (northern side). Endemic to Kyrgyzstan (Fig. 3). Growing among juniper thickets on carbonatic rocks, at 1700-1800 m a.s.1.

Conservation status. The species is known from a restricted territory ca. $5 \mathrm{~km}$ wide, whose extent is estimated at $8-10 \mathrm{~km}^{2}$. The species' population is estimated to include 2000 mature 


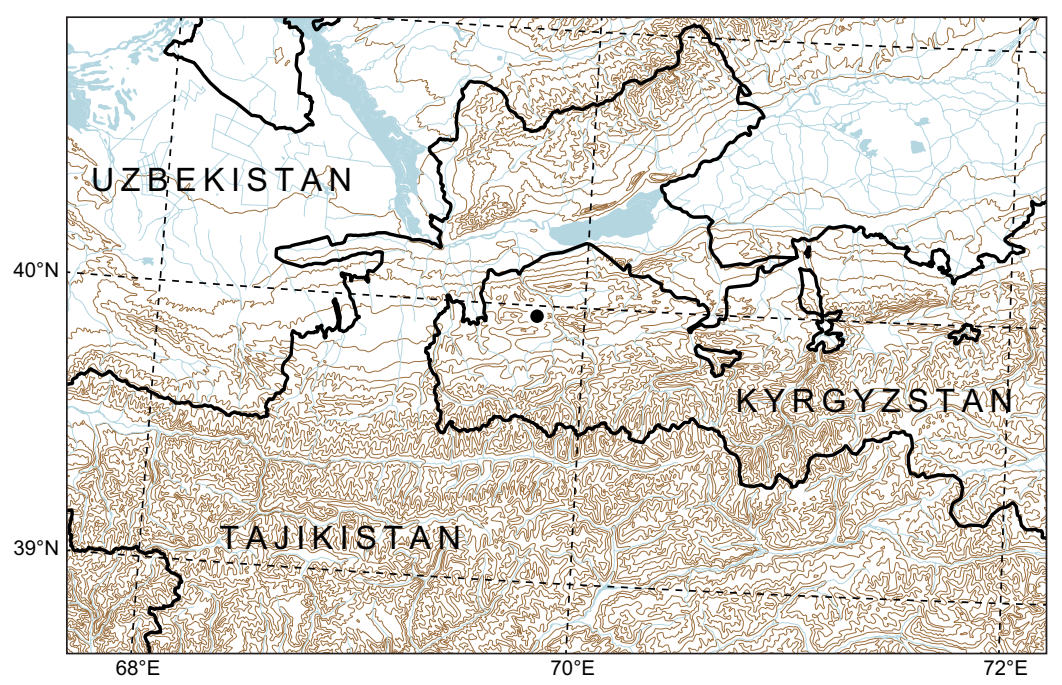

Fig. 3. Distribution of Ligularia philanthrax. individuals. The population seems to be healthy and many individuals were observed in flower, although cattle damage was also visible. The population is situated within a coal mining area at Sülüktü, which is among the largest and most intensely exploited coal fields in the country, and therefore is under apparent risk of extinction. The species is therefore assessed as Critically Endangered (CR) according to the criteria B2ab(i) (IUCN 2012). Its distribution lies outside protected areas.

According to the taxonomic system of Pojarkova (1961), L. philanthrax is tentatively classified in L. sect. Glossophyllum because of the presence of reduced scale-like basal leaves. As evident from other characters of flowering heads and the plant habit, this species and its presumably close relative $L$. pavlovii are also very similar and probably related to the species of $L$. sect. Senecillis, as compared by Pojarkova (1961). So far, a sufficient phylogenetic study of Ligularia is lacking, and the available phylogenies (Liu et al. 2005, Pelser et al. 2007) do not provide any insight into species relationships within the genus.

Reduced scale-like basal leaves of L. philanthrax and L. pavlovii, which persist within a season and do not wither early like smaller-size outermost rosette leaves, seem to function as cataphylls that are acting as bud scales. In these species, developed basal leaves at the base of flowering stems are lacking. Developed basal leaves that look like belonging to flowering stems are formed in axils of reduced scalelike leaves and actually belong to the first-year growth of dicyclic shoots that will produce a flowering stem but no developed basal leaves during the second year.

In species of $L$. sect. Senecillis, rosette bud scales are lacking and outermost rosette leaves are not reduced to sheaths. This difference in shoot structure is very similar to that observed in Ranunculus cassubicus and $R$. auricomus (Serebryakov 1952). Since its taxonomic value in Ranunculus is undoubtedly infrasectional (Tzvelev 2001), the placement of L. philanthrax and $L$. pavlovii into a separate section seems to be unjustified and their relocation to $L$. sect. Senecillis is suggested.

The large disjunction between distribution areas of $L$. philanthrax and L. pavlovii is not very surprising. The number of isolated taxa at different ranks in Central Asia is quite high, making this territory a hotspot of diversity of flowering plants (Mittermeier et al. 2011). Recent phylogenies (e.g. Kilian et al. 2017) continue uncovering ancient lineages in this territory. Another example of disjunct distributions between the Syrdaria Qarataý in the Western Tian-Shan and the Pamir-Alay Mountain System in an isolated plant group can be seen in the genus Autumnalia (Apiaceae). So far, that genus has two representatives (Pimenov 1989), both being narrow endemics in two remote territories: one in the Syrdaria Qarataý, the other in the Nurota Mts. 
(the westernmost part of the Hissar-Alay that also includes the Turkestan Range).

With L. philanthrax, there are 18 species of the genus in Central Asia, of which four are narrow endemics. This discovery brings further evidence that the inventory of Central Asian flora is far from completion, and its newly recorded species may be critically endangered because of very intensive grazing and extensive mining in this territory.

\section{Acknowledgements}

Sampsa Lommi (Helsinki) skilfully produced the map. This study was supported by the Central Asia Green Road Project (KNA1-1-17, 15-2), jointly developed by Korea and Central Asian countries.

\section{References}

Ganybaeva M.R. [Ганыбаева M.P.] 2009: [Flora of the watershed of the Isfana and Laylak rivers (Turkestan Range)]. - National Academy of Sciences, Bishkek. [In Russian].

IUCN 2012: IUCN Red List categories and criteria, version 3.1, 2nd ed. - IUCN, Gland \& Cambridge.

Kamelin R.V. [Камелин P.B.] 1990: [Flora of the Syrdarla Qarataý]. - Science Publishers, Leningrad. [In Russian].

Kilian N., Sennikov A.N., Wang Z.H., Gemeinholzer B. \& Zhang J.W. 2017: Sub-Paratethyan origin and Middle to Late Miocene principal diversification of the Lactucinae (Compositae: Cichorieae) inferred from molecular phylogenetics, divergence-dating and biogeographic analysis. - Taxon 66: 675-703.

Lazkov G.A. \& Sennikov A.N. 2017: Taxonomy of two blueflowered juno irises (Iris subgen. Scorpiris, Iridaceae) from the Western Tian-Shan. - Annales Botanici Fennici 54: 297-305.

Lipschitz S. 1931: Senecio Pavlovii, species nova Karatau montium Turkestaniae Rossicae. - Repertorium Specierum Novarum Regni Vegetabilis 29: 162.

Liu S.W. \& Illarionova I.D. 2011: Ligularia. — In: Wu Z.Y., Raven P.H. \& Hong D.Y. (eds.), Flora of China 20-21: 376-415. Science Press, Beijing \& Missouri Botanical Garden Press, St. Louis.

Liu S.W., Wang Y.J., Wang A.L., Hideaki O. \& Abbott R.J.
2005: Radiation and diversification within the LigulariaCremanthodium-Parasenecio complex (Asteraceae) triggered by uplift of the Qinghai-Tibetan Plateau. Molecular Phylogenetics and Evolution 38: 31-49.

Mittermeier R.A., Turner W.R., Larsen F.W., Brooks T.W. \& Gascon C. 2011: Global biodiversity conservation: the critical role of hotspots. - In: Zachos F.E. \& Habel J.C. (eds.), Biodiversity hotspots: distribution and protection of conservation priority areas: 3-22. Springer Verlag, Heidelberg.

Nordenstam B., Pelser P.B., Kadereit J.W. \& Watson L.E. 2009: Senecioneae. - In: Funk V.A., Susanna A., Stuessy T. \& Bayer R. (eds.), Systematics, evolution \& biogeography of Compositae: 503-535. IAPT, Vienna.

Ömürzakov S.Ö., Keshikbaev A.A., Makhrina L.I., Eshenkulov T. \& Ryskulbekova B. [Умурзаков C.У., Кешикбаев А.А., Махрина Л.И., Эшенкулов Т. \& Рыскулбекова Б.] 1988: [A dictionary of toponyms of the Kyrgyz SSR]. - Science Publishers, Frunze. [In Russian].

Pelser P.B., Nordenstam B., Kadereit J.W. \& Watson L.E. 2007: An ITS phylogeny of the tribe Senecioneae (Asteraceae) and a new delimitation of Senecio L. Taxon 56: 1077-1104.

Pimenov M.G. [Пименов М.Г.] 1989: [Autumnalia - a new genus of Apiaceae endemic to Central Asia, with two new species]. - Botanicheskii Zhurnal (Moscow \& Leningrad) 74: 1488-1495. [In Russian].

Pojarkova A.I. [Пояркова А.И.] 1961: Ligularia. — In: Schischkin B.K. \& Bobrov E.G. [Шишкин Б.К. \& Бобров Е.Г.] (eds.), [Flora of the USSR] 26: 788-57. Academy of Sciences of the USSR, Moscow \& Leningrad. [In Russian].

Serebryakov I.G. 1952: [Morphology of vegetative organs in higher plants]. - Soviet Science State Publishers, Moscow. [In Russian].

Turland N.J., Wiersema J.H., Barrie F.R., Greuter W., Hawksworth D.L., Herendeen P.S., Knapp S., Kusber W.-H., Li D.-Z., Marhold K., May T.W., McNeill J., Monro A.M., Prado J., Price M.J. \& Smith G.F. (eds.) 2018: International Code of Nomenclature for algae, fungi and plants (Shenzhen Code) adopted by the 19th International Botanical Congress Shenchen, China, July 2017. - Regnum Vegetabile 159: 1-254.

Tzvelev N.N. [Цвелев Н.H.] 2001: Ranunculus. - In: Tzvelev N.N. [Цвелев H.H.] (ed.), [Flora of East Europe] 10: 100-158. World and Family Publishers \& Saint-Petersburg State Chemical-Pharmaceutical Academy, Saint-Petersburg. [In Russian].

Zuckerwanik T.I. [Цукерваник Т.И.] 1993: Ligularia. In: Adylov T.A. \& Zuckerwanik T.I. [Адылов Т.A. \& Цукерваник Т.И.] (eds.), Conspectus Florae Asiae Mediae 10: 441-448. Academy of Sciences of the Uzbek Republic, Tashkent. [In Russian]. 